\title{
Crossover Dreams: Global Circulation of Queer Film on the Film Festival Circuits
}

Copyright (c) ICPHS 2016 Reprints and permissions: sagepub.co.uk/journalsPermissions.nav DOI: 10.1I77/0392192II56670I4 dio.sagepub.com

(SAGE

\section{Skadi Loist}

University of Rostock, Germany

\begin{abstract}
The ubiquity of gender-bending and sexually ambiguous imagery in the media seems to herald a post-gay era. But are LGBT/Q identities and representation politics really a thing of the past? Inspection of the circulation patterns of LGBT/Q images on a global scale suggests a more nuanced story. Taking the lead from distribution and film festival studies, in this essay I sketch out how LGBT/Q images travel around the world. The festival network was always an alternative channel to mainstream work. Therefore, I pay particular attention to the international film festival circuit with its art film bias, on one hand, and activist festivals, such as LGBT/Q film festivals and their LGBT/Q-themed films, on the other. Utilizing Lisa Henderson's notion of "queer relay" I argue that the relationship between the queer film ecosystem and the larger art film circuit is highly ambivalent. The deployed art film strategies reveal that we have not yet arrived at actual acceptance and universality in a post-gay, post-identitarian world. However, the positions on the side of distinction and cultural capital do not just lean towards exploitation of queer subcultural productions by neoliberal forces but offer also a relay position that accounts for queer agency in the wider cultural arena.
\end{abstract}

The ubiquitous nature of gender-bending and sexually ambiguous imagery in mainstream media seems to suggest that we live in happy liberal post-gay times. A bearded drag queen persona from Austria named Conchita Wurst wins the Eurovision song contest 2014, uniting a Europe which was thought to be divided over issues of gender and sexuality (normatively thought to move from liberal West to conservative South-East). ${ }^{1}$ One year earlier, the most prestigious art film award, the Palme d'Or, went to a film featuring the coming of age of a young woman with a full-on seven-minute unabashed same-sex sequence in La Vie d'Adèle/Blue is the Warmest Color. And the Guardian recently announced the arrival of a New-Wave Queer Cinema (Walters, 2012). But is it all really that easy? Are lesbian gay bisexual trans* queer $\left(\mathrm{LGBT} / \mathrm{Q}^{2}\right)$ identities and representation politics a thing of the past and have gender and sexuality become non-dualistic concepts in media and society?

Closer inspection of the circulation of LGBT/Q images on a global scale suggests a more nuanced story. In the following essay, I take the lead from current distribution studies as well as

\section{Corresponding author:}

Skadi Loist, Universität Rostock, Philosophische Fakultät, Institut für Medienforschung, August-Bebel-Straße 28, I8055

Rostock, Germany.

Email: skadi.loist@uni-rostock.de 
film festival studies and aim to sketch out the ways in which LGBT/Q images travel around the world. As Ramon Lobato has distinctly put it, the "circuits through which texts move are of paramount importance to the processes of reception" (2007: 114). One main channel in contradistinction to mainstream work was always the festival circuit. Therefore, I will pay particular attention to the film festival circuits and the flow of global art cinema. Here two main strands are of interest: the international film festival circuit with its art film bias, and activist festivals, such as human rights and LGBT/Q film festivals and their LGBT/Q-themed feature films.

\section{Current queer film}

When considering the global circulation of queer images in recent years, one needs to start asking what the term "queer cinema" signifies today. In the broadest sense "queer cinema" could serve as an umbrella term for films which convey LGBT/Q imagery, narratives or sensibilities. Here a number of qualifications and differentiations for a nuanced consideration of recent trends are possible and necessary. What counts as queer cinema is a complex story. The definition of the lowest common denominator would be the presence of queer characters in the narrative. Yet, the context of the production and distribution as well as their framing have a significant influence on the appropriation and embrace of reception contexts. Within this framing process the demarcation lines between categories, such as queer vs. heteronormative, mainstream vs. community, queer cinema vs. art film, auteur status vs. indie filmmaker become visible. These in turn frame how films will be perceived and travel along the circuit, and whether they will be embraced by queer audiences which have been informed by the programming choices of LGBT/Q film festivals.

Following the historical development of LGBT/Q politics and representation, queer film has developed in a number of different ways. While dominant Hollywood film sought to exclude and negate homosexuality and non-normative forms of representation of gender and sexuality through the Production Code (1930-1968), counter representations developed in the American underground (Kenneth Anger, Andy Warhol, Jack Smith) and European avant-garde cinema (Jean Genet, Derek Jarman etc.). Emerging gay liberation politics and (lesbian) feminism in the 1970s resulted in a call for self-produced images, which favored a positive representational regime. In the middle of the 1980s then, a small Gay New Wave appeared with such successful independent films as Personal Best (1982), Lianna (1983), My Beautiful Laundrette (1985), Mala Noche (1985), Desert Hearts (1986), and Parting Glances (1986). In the late 1980s, as the height of the AIDS crisis translated into radicalized queer politics and avant-garde aesthetics exuded urgency and defiance, a flock of films which denied the regime of positive imagery and told stories from a different point of view, films not pleading for tolerance or explaining gay and lesbian lifestyles to a straight majority audience appeared on the film festival circuit and came to be branded as New Queer Cinema by critic B. Ruby Rich (1992). The critical acclaim, visibility and cross-over success of the New Queer Cinema in turn paved the way for the establishment of a niche market and further assimilation of LGBT/Q stories into the mainstream (Rich, 2000).

Since the 1990s, a large number of films featuring LGBT/Q characters and storylines are produced yearly. Yet, not all find their way into the mainstream, nor do they all aim to do so. Instead with the proliferation comes a differentiation, that is a differentiation in address, in aesthetics and representation, in marketing and circulation: for one, there are independently produced films, which aim at a community audience; secondly, there are independent film productions with ambitions for cross-over success; and thirdly, global arthouse films, which employ tropes of gay/queer characters without a desire to fare as LGBT/Q film. For a long time, Hollywood could only handle coy tolerance films, which were desexualized in order to plea for the "humanitarian" appeal (think of Philadelphia in 1993) or top-grossing raunchy comedies (from The Birdcage in 1996 to Brüno in 20093). The watershed film for cross-over representation came with Brokeback Mountain 
(2005), which queered the quintessential American genre of the Western and literally played in multiplexes all around the globe.

Various critics and scholars have tried to classify recent productions that could fall under the rubric of "queer cinema" often in reference to the definition of the break-through New Queer Cinema (NQC). Ben Walters calls the turn away from both the typical coming-out narrative that was a staple of 1990s LGBT/Q cinema and the rebellious NQC to a more nuanced story-telling in films that "deal with real life and rounded characters" the New-Wave Queer Cinema (Walters, 2012). Some of his examples are festival darlings such as Ira Sachs' Keep the Lights On (2012) or Andrew Haigh's Weekend (2012). Michele Aaron has recently argued for a kind of queer cinema that employs the radicalness of early 1990s queer politics, and - using Hamid Naficy's concept of accented cinema ${ }^{4}$ - engages the intricately tied discourses of "race and nation, gender and sexuality, to reveal the accented as queer and the queer as accented" (2012). Using the German lesbian queer film Fremde Haut/Unveiled (2005) as an example, Aaron argues "ultimately, what is distinguished is the potency of a new 'quare' cinema" (2012: 323). Working on a project of global queer cinema, Rosalind Galt uses Tan de repente/Suddenly (2002) as an example to call for a larger framing of queer cinema through the lens of the economic concept of "default," arguing for the inherent queerness in terms of aesthetic as well as economic refusal of what she calls a "global default cinema" (Galt, 2013).

All these scholars try to rescue the political project "queer" in their theorizations of queer cinema. Often the films discussed in this vein are films with attested artistic merit and progressive politics, in terms of both representational regimes and critical anti-identitarian, anti-capitalist politics. Yet, there is a larger shift visible on the art film circuit, one that could be said to reflect larger social developments in terms of representation of sexuality and gender. J. Jack Halberstam has recently pointed out in Gaga Feminism (2012) how vast shifts in the social (US-American) fabric have become visible in everyday life, popular culture, and media representation. Mainstream cinema seems to respond to the crises of gender (or the crisis of white hetero cis-masculinity) with a backlash variety of "romcoms" or "bromances," featuring male failures who nevertheless win the attractive, ambitious, and beautiful woman (Halberstam, 2012: 17-22). American independent and global art films, on the other hand, seem to explore completely opposing concepts.

Ever more films deal with overt sexuality in all its non-normative and kinky details: spanning from Travis Mathews \& James Franco's pseudo-documentary Interior. Leather Bar (2013), which is based on the musings of what the 40-minute cut sequence of William Friedkin's then scandalizing gay slasher film Cruising (1980) might have looked like, to Stacie Passon's imagination of a suburban forty-something lesbian, who turns to sex-work to spice up her life in Concussion (2013) from the community side. At the same time on the arthouse side, straight filmmakers continue the trend of utilizing queer moments as narrative devices. There have always been films featuring lesbians - like the small wave of killer lesbian films (Rich, 2013) - which were mostly made by male independent filmmakers or auteurs. The recent season has seen a renewed interest in the lesbian as a discursive figure rather than an identitarian character. Prominent examples are Cristian Mungiu's Dupã Dealuri/Beyond the Hills (2013) or Denis Côté's Vic +Flo ont vu un ours/Vic and Flo Saw a Bear (2012). More attention gained Lars von Trier's latest controversial offering on female sexuality in Nymph()maniac 1+2 (2014), and Abdellatif Kechiche's La Vie d'Adèle - Chapitres 1 \& 2 (2013), which also brought up controversy about explicit (lesbian) sex while building on queer cultural production through adaptation.

While B. Ruby Rich (2000) has already contended around the turn of the century that queer cinema was reaching higher production values and cross-over, a new quality of circulation is visible. Looking at the offerings at the A-list film festival circuit and especially the "big three" European festivals (Cannes, Berlin, Venice) it becomes apparent that recent art cinema has reached a peak in terms of a queer sensibility. Or rather a peak in the convergence of queer cinema and art cinema. 
On the one hand, queer cinema of the variety that originates from the community-spectrum and used to signify a minority cinema moves further into the center or rather up the hierarchies of Bourdieusian distinction. On the other hand, within auteur-oriented art film, operating without any stakes or interests in community politics, the anti-identitarian ideas of sex and gender, which used to be one central issue of queer progressive politics, have also caught on.

This peak of queer cinema translates into a long list of "queer" films premiering at the international film festival circuit. Especially the queer-themed awards and groups, such as the Teddy Award at the Berlinale (since 1987), the Queer Lion at Venice (since 2007), the Queer Palme at Cannes (since 2010), or the Queer Lounge at Sundance (2004-2011) provide condensed glimpses into the premiere pool of LGBT/Q films at top-tier film festivals. Taking a look at those festivals and their LGBT/Q awards lists over the last few years reveals such impressive numbers as 30-40 LGBT/Q films screened at the Berlinale yearly (including about one-third documentaries and onefifth shorts), between seven and 19 LGBT/Q films at Venice depending on the year, roughly 10 LGBT/Q-themed films at Cannes, and 20-40 LGTB/Q films at Sundance. ${ }^{5}$ Even though not all of these films are world premieres - some films regularly screen at Sundance and crop up later at a sidebar section in Berlin for instance - this gives impressive numbers of the output of queer cinema. And this is only the list of films that premiere at the top-tier festivals. Further independent productions additionally premiere at festivals of the LGBT/Q festival subcircuit.

The Berlinale has a decade-long tradition of presenting LGBT-themed and authored work, notably in the Panorama section but also in the other sidebars. In Berlin as well as Venice and Cannes, queer films have moved from the side bars to the center, entering the main competitions and even winning the top awards. Recent LGBT/Q hits at the Berlinale included the Out of Competition screening of Lisa Cholodenko's The Kids Are All Right (2010); Tomboy (Céline Sciamma, 2011) opened the Panorama; and the last three festival editions have seen LGBT/Q films in the competition section even as opening film: Les adieux à la reine/Farewell, My Queen (Benoît Jacquot, 2012), W imię.../In the Name of (Małgorzata Szumowska, 2013) and Praia do Futuro (Karim Aïnouz, 2014). While Venice does not seem to be the forerunner of sexually transgressive or queer film, several important cross-over films premiered there: most notably the watershed film Brokeback Mountain won the Golden Lion in 2005. At the Cannes film festival in 2013, several queer-themed films garnered critical acclaim, most notably the Palme d'Or was awarded to director Abdellatif Kechiche and main actresses Léa Seydoux and Adèle Exarchopoulos for La Vie d'Adèle-Chapitres $1 \& 2$. And the list of awards to films with a queer sensibility at Cannes 2013 goes on: Cristian Mungiu's Beyond the Hills; wunderkind Xavier Dolan's third feature Laurence Anyways, and Alain Guiraudie's L'Inconnu du lac/Stranger by the Lake.

While all these films have premiered at A-list festivals, not all travel on the circuit with the same cultural capital. The circulation and exhibition pattern depends on a variety of markers and how these are foregrounded or interrelated. When trying to see the markers that have an influence on further circulation, the following concepts seem to play a role in marketing and branding: sexuality vs. identity, universality vs. community, auteurs vs. independent (low-budget) filmmakers. While these terms are listed as binaries or oppositions, some of those categories fall together or cannot be aligned strictly on one pole or the other. Thus, within the scope of this essay, I will not be able to offer a clear taxonomy or template of how films will travel on the circuit. Yet, I want to look at a few examples in the recent field to try and extrapolate some trends and mechanisms that might emerge as a pattern.

\section{Film festival circuits}

Film festivals are of significant importance for the circulation of arthouse film. The festival circuit has become an alternative distribution/exhibition network that is showing films to cosmopolitan 
cinephiles in international urban centers (Wong, 2011). Festivals provide circulation of art film either before or instead of theatrical releases. It is a circuit operating in tandem with - or where arthouse cinemas are in decline and no theatrical release possible, the international film festival becomes the site for - art film consumption. The film festival is the building block for word-ofmouth promotion of art cinema, where the national or regional premiere is used to launch the following arthouse cinema run. Thus, film festivals function to some degree as the counterpart to commercial cinema distribution. Thus, Marijke de Valck (2007) has argued that the film festival network operates as an alternative distribution network.

While commercial cinema (mainstream Hollywood, but also other global blockbuster productions) also use film festivals for deal-making, generating attention, and to a launch a film with big buzz and some glamour, film festivals are equally feared for negative criticism that might follow in a competition selection. Thus, many mainstream productions only play "out of competition," so that both film industry and festival assure the use of the event to mutual advantage: the festival gets a glamorous red carpet and the film big press without running the risk of "losing." Art film on the other hand, largely relies on the forms of distinction provided by film festivals and the circuit. Film festivals - like the art film genre - are largely built on cinephilia and auteur politics (Andrews, 2013). These are circuits that follow mechanisms of artistic valuation and cultural capital in the Bourdieusian sense that feed into the film festival structure as well as arthouse circulation.

The global film festival network consists of more than 6,000 festivals. ${ }^{6}$ On this vast circuit there is room for many films and wide exhibition. Yet, clearly not all of these festivals serve the same functions or operate on the same level within the larger system. Indeed, the film festival circuit is highly stratified and differentiated. One can discern several ranked tiers of festivals as well as several parallel circuits or subcircuits (see Iordanova, 2009). Marijke de Valck (2007) and Thomas Elsaesser (2005) have proposed the model of the film festival network in which festivals operate as hubs and nodes. The most important nodes, or relay stations, which function as essential forces in the flow pattern in the larger network, are the top-ranked or so-called A-list festivals. ${ }^{7}$

Below the A-list level, there follow various levels of lower-ranked "international film festivals" with general programming scope. Those second- and third-tier festivals still offer essential services on the business side of the festival circuit, but might be limited in reach compared to the core of top-tier festivals such as Cannes, Venice, Berlin, and Toronto, but may still act as leading events for professionals in their region or country (De Valck, 2014: 47-48). In parallel several specialized circuits are in play which are interconnected with the overarching circuit of festivals with general programming scope, but which themselves build their own hierarchical system with core and periphery or top/second/third tiers. Festivals with genre or format specifications, which from a commercial film business angle count as "minor cinemas," such as documentary, animation, or short film festivals, equally form their circuits, with premiere status, co-production markets, talent labs etc. Apart from those a whole host of other small, specialized festivals exists that are usually centered on social concern issues or identities, such as feminist, Jewish, and Black film festivals, diasporic and national cinema festivals, human rights, ecology, or LGBT/Q film festivals. ${ }^{8}$

LGBT/Q film festivals started as counterpublic spheres and places committed to counter negative representation and bring about pride and visibility, the key tenets of the gay liberation movement in the 1970s, the time when the first LGBT/Q film festivals started to appear. The longest-running festival, the Frameline: San Francisco LGBTQ Film Festival dates back to 1977 and has grown to become the biggest of its kind that serves as flagship and trend-setter for other festivals (Loist, 2008). Over the last three decades the queer film festival circuit has grown substantially, now covering most regions of the globe with about 230 festivals being active. ${ }^{9}$ As with the non-specialized festivals, the queer festival circuit has stratified and about 15-20 festivals can be said to belong to the top-tier festivals within this specialized circuit, with the privilege of 
screening LGBT/Q films as regional if not international or world premieres and being an active part of the queer film ecosystem.

For our concerns of the global circulation of LGBT/Q films, the general circuit of so-called "international film festivals" (IFF), i.e., the A-list as well as second- and third-tier festivals without specialization, and the specialized circuit of LGBT/Q film festivals (QFF) are of interest. Taking a look at the interconnections between those circuits and parallel or sub-circuits is illuminating in terms of distinction and market clout, i.e., cultural and financial capital.

The highest ranked festivals provide the most privilege and press via their cinephilic system. As "business festivals" (Peranson, 2008) they also act as power brokers for distribution deals and as intermediaries for future productions. Apart from the commercial deals being struck at their adjunct markets, the big film festivals via their attending professionals are places of essential value-addition (De Valck, 2007). Cultural value and distinction are built by various mechanisms of selection which translate into value-addition processes from pre-selection to programming and awards juries (De Valck and Soeteman, 2010) and by mediatization. The buzz created by trade journalism and boulevard magazines helps generate or strengthen the promotion and flow of product. For this reason, films start their festival run - and with this their life in the distribution flows - at the highest ranked festival they can get into. From there they will trickle down through the tiers of IFFs and QFFs.

This ranking system is resting on an ideology of premiere status. Due to this mechanism A-list festivals are essential nodes in the film festival network. They dictate the timing of deals and releases and are the relay switch points for the subsequent flow of films through the festival and exhibition circuits. The premiere at a top-tier festival assures the attention of buyers, press, and programmers of other festivals. Along with open submissions the scouting and active invitation of films into a festival program is the most important part for program selection, both for the profilebuilding of a festival, but also for the flow of festival films. Thus, programmers attend A-list festivals or agenda-setting second-tier festivals, such as Rotterdam and Sundance to scout for films that they will present as local premieres to their home audiences and their (release) market. Second and third-tier festivals especially can either act as discovery festivals for local distributors and cinema programmers of the arthouse circuit or as direct launch pads for local releases. As we have seen above, the A-list festivals have shown increasing numbers of queer-related films that are then going into further circulation on the IFF or QFF circuits. Here, the premiere status does play a significant role for the routing of the further festival run. ${ }^{10}$ Films from Cannes (May), might go on to second/third-tier festivals such as the German Filmfest München (in June, e.g., La Vie d'Adele) or Filmfest Hamburg (in September, e.g., Beyond the Hills).

For queer-themed films the Berlin International Film Festival (Berlinale) is of specific importance. The festival has shown decade-long dedication to support LGBT/Q film through programming, first in the Panorama section, established by Manfred Salzgeber in 1980, and initiating the Teddy award for queer film screening across all sections at the Berlinale in 1987. This longstanding combination of programming and attention generated by an award led to the organic development of a huge following of LGBT/Q festival programmers to the Berlinale, which is now semi-institutionalized in the annual Queer Programmers Meeting hosted at the festival. By sharing information of films and festivals, this meeting performs and consolidates a network of people who are essentially the core actors in the global QFF circuit. In recent years this meeting has become an informal pitching arena for independent filmmakers and their queer-themed projects, which aim for a successful LGBT/Q festival run.

To a great degree the European festival model is built ideologically in contradistinction to Hollywood with its market-driven, mainstream-oriented logic. ${ }^{11}$ In order to compete with the financial power brokering of blanket releases and the buzz machinery generated by marketing capital, the festival system has developed its system of value-addition that offers cultural capital 
which seeks to compensate for lack of finances. Thus, festival buzz and prestigious awards help to build distinction for a film, which helps it travel on the festival circuit and further onto the arthouse distribution circuit. In (very) rough schemata one could say that film festivals are for art film what mainstream multiplexes are for Hollywood studio films. The film festival system, initially propelled by the European festival system, elevated European art film and since the 1970s global art cinema by way of the discovery imperative of new national film waves (cf. Stringer, 2001; Farahmand, 2010).

The differentiation of the US film market and the rise of independent film also went in tandem with the development of US film festivals. Sundance, the quintessential festival of US-American independent film, is for US independent film and the North-American arthouse market what Cannes is for global art cinema: the major hub for premieres and industry attention. Thus, for American arthouse film, especially with regard to diversity, Sundance is the top-ranked festival for LGBT/Q content on the North-American market. Not surprisingly critic B. Ruby Rich has declared the existence of the New Queer Cinema after a festival roundup that started with Sundance (1992). For queer-themed indie films Sundance is for the American market what Berlin is for Europe. There has long been a strong presence of queer film in the selection and important American queer films have been programmed, discovered, and bought at Sundance. ${ }^{12}$ Similar to the Queer Programmers Meeting hosted in Berlin, the Queer Lounge at Sundance (2004-2011) offered a platform and hosted panels and events to promote LGBT/Q film and talent.

\section{Distribution and the "gay ghetto"}

Not all films have equal interest or chance to travel the IFF or QFF circuits, though. Similar to the premiere appeal and launch factor at top-rank festivals with the trickle-down logic, the ideal of distribution is to reach the most screens and paying audiences possible. Thus, the higher ranked a festival, the more likely that a buyer (distributor or other license holder) will be in attendance and offer a deal. "Big" productions make international distribution deals with licenses for various territories sold. The next step after the premiere at a top-ranked festival is a subsequent festival run at second/third-tier IFFs and the specialized circuit. The strategies of how a film is exhibited on the circuit depend on the interests of the producer or local distributors. Some distributors fully embrace the festival circuit as an alternative distribution system, i.e., an outlet in its own right and its ability to generate press for a national launch and/or a revenue stream.

It should be noted that for a small, independent, low-budget LGBT/Q film a run on the LGBT/Q circuit can be a lucrative revenue stream in its own right, even when the traditional route of a theatrical release is out of reach. The Film Collaborative (TFC, www.thefilmcollaborative.org), a non-profit organization committed to distribution and facilitation of independent film, published numbers for possible revenue income from the festival run based on case studies of films represented by TFC (The Film Collaborative 2013). ${ }^{13}$ Specifying income for LGBT/Q-themed films, they list incomes ranging between US\$ 5,000 and 87,000, with a medium of about US\$20,000. When talking about revenue patterns, they generate specific film categories which follow along the lines of estimated revenue markers: (1) Where did the film premiere, and (2) Does the film fit into a niche? Thus, the aforementioned markers of premiere status and specialized circuits can be said to translate directly into revenue, at least for low-budget independent films. Similar findings are suggested in a study that estimates the premiere impact of A-list festivals (cf. Mezias et al., 2011).

The producers and specialized distributors, who embrace the QFF circuit and work in tandem with it, have grown into a queer film ecosystem (Olson, 2002). ${ }^{14}$ The queer ecosystem operates largely on community logic, i.e., it can be said to be stigmaphilic, and banks on community credibility (cf. Henderson, 2013). Within this context, actors and filmmakers work largely connected to the ethos that QFFs have operated and programmed on for decades: the support and privileging 
of work "by, for and about," sometimes with the addition "of interest to" the LGBT/Q community (cf. Loist, 2012: 163). The QFFs have grown and cultivated a specialized audience over the years, which is now easily catered to and has been tapped into by specialized distributors as well as mainstream circuits acknowledging niche marketing (cf. Moore, 2013: 139).

This ecosystem does not work completely independently of the larger media industry and distribution circuits. The queer ecosystem and its LGBT/Q audiences are well-defined groups that help define a market for films with LGBT/Q content, yet some distributors and filmmakers are still afraid of the "gay ghetto." 15 While they might happily consider to exploit that defined market bracket, it is only seen as an add-on, a secondary or tertiary route in marketing. The logic behind this is apparently still that LGBT/Q identity politics and marketing are show-stoppers for the general (read: universal) market. Thus, some distributors refuse circulation on the LGBT/Q circuit. Here, varying arguments can be discerned. One example is Céline Sciamma's second feature film Tomboy, which premiered at the Berlinale as opening film of the Panorama section in February 2011. When the Hamburg International Queer Film Festival wanted to screen the film (in October) the distributor objected with the argument that the Französische Filmtage Tübingen | Stuttgart was slated to showcase the film (in November). Even though this festival might be of some relevance for French film in Germany, in the grand scheme of the festival circuit it has a negligible audience reach and press impact. The Hamburg queer film festival, on the other hand, is the biggest LGBT/Q festival in Germany, with a sizable audience and impact in generating word-of-mouth for subsequent theatrical release and DVD sales. The assumption that the distributor was weary of launching the film at a "gay ghetto" festival seems obvious. Even the argument that Tübingen would insist on a "premiere" made no sense as the film had indeed premiered at Berlin in the national A-list festival earlier that year. In addition, personal communication between festivals revealed that neither festival saw any competition or had any interest in being a "premiere" spot for the film. These and other stories continue to come up over the years, even though shifts in the social fabric and media market are visible. Yet, fear of stigma seems still big.

Another example where marketing interests of arthouse exploitation and LGBT/Q community politics intersect or oppose each other is the case of a "big" distributor that is unconcerned with a festival run beyond a few launch pads. As one concrete example we could take Dee Rees' feature debut Pariah (2011). In the film African-American Brooklyn-based 17-year-old Alike juggles conflicting identities and risks friendship, heartbreak, and family in a desperate search for sexual expression. The film premiered to critical acclaim, won a cinematography award at Sundance, and was bought by Focus Features. ${ }^{16}$

Focus Features is a very successful studio specialty arm of Vivendi Universal with a specific brand identity, which is well-versed in the successful distribution of films exploring questions of gender, sexuality, and sexual identity (cf. Tzioumakis, 2012: 177-178). A journalist described the company's approach as "aggressive, they take big chances on little movies that have big payoffs, and they aren't afraid of dangerous ideas and rogue filmmakers" (Ibid.). Among the successful films with queer-themed content or queer auteurs that Focus Features represented are the critically and commercially successful Far From Heaven (Todd Haynes, 2002), Brokeback Mountain (Ang Lee, 2005), Milk (Gus Van Sant, 2008) - a biopic about Harvey Milk - and The Kids Are All Right (Lisa Cholodenko, 2010). Considering this slate of independent films it is no surprise that Focus Features took on Pariah and handled it the way it did. Basically, Focus Features can be characterized as aiming for a wide arthouse audience, going beyond the LGBT/Q niche that filmmaker Dee Rees had already successfully become a part of with the run of the short film version of Pariah (2007) which travelled widely on the QFF circuit to great acclaim. It went to all the important LGBT/Q festivals in the US (Newfest, Frameline, Outfest) and internationally as well as several IFFs such as Sundance, Los Angeles, and Athens, and won several awards. 
The short film had been supported by the LGBT/Q community-oriented Frameline Completion Fund, established in 1990. The Frameline Completion Fund was born out of the insight that a queer festival organization dedicated to a nuanced representation of the LGBT/Q community cannot sit back and lament the lack of queer films, even more so from structurally underrepresented and underressourced parts of the LGBT/Q community (especially women, trans*, ${ }^{17}$ and queers of color) but that they need to actively encourage and support the production and completion of such works. ${ }^{18}$

The successful short, which had been the film school thesis project derived from the feature film manuscript of the same title, became the basis for the development of the feature version. Writer/ director Dee Rees and producer Nekisa Cooper assert how hard it was to find financing for the film despite the success and critical acclaim of the short film and in-kind institutional support from festival-related programs. Dee took part in the Sundance Screenwriters' Lab in 2007, the Director's Lab in 2008, while Cooper went to the Sundance Producers' Lab in 2008 (Focus Features, 2011). Despite these opportunities and ideological backing from independent film institutions such as Sundance Institute, Tribeca Film Institute, and Independent Feature Project, funding remained tough; Cooper recalls that the "script was [considered] really good and edgy, but a bit 'small' and "specific"" (Focus Features, 2011). The filmmaking team invested private funds, and after five years in production turned to crowd-funding to generate money for finalization and music rights, and in addition received another Frameline Completion Fund grant in 2010. ${ }^{19}$

This story attests to the recognition of emergent talent and the precarity of the independent low-budget project due to its representational profile as a queer-of-color debut feature. In the move from short film to feature a significant shift in terms of framing and marketing becomes visible. Along the way, mentor Spike Lee was attached as executive producer. Together with the valorizing narrative of dedicated young talents, the Focus Feature website of the film highlights the collaboration with auteur figure Spike Lee and the cinematography award from Sundance (focusfeatures. com/pariah). This narrative with auteurist spin seemed to override the LGBT/Q community background, which had been fertile ground for Dee Rees's personal and professional development.

Considering the supportive role the QFF and IFF circuits had played in backing the young filmmaker and her project, one would expect that the feature film would have an equally successful run on the festival circuit. Instead, Focus Features focused on a few key festivals to launch the film with the strategy of generating buzz for a successful arthouse run that would not exactly oppose the queer background and audience, but was also not showing any loyal obligations. This becomes most visible in the fact that despite Frameline having supported filmmaker and project in both the short and feature version in promotion and funding, the festival was denied the privilege of screening the film as a West-Coast community festival premiere before the scheduled theatrical release. Instead, Frameline was left to organize a discussion with filmmakers and crew at the festival, but could not show the film. ${ }^{20}$

In a similar vein, the film did not go on a large festival run outside the US market. Several European queer film festivals were hoping to screen Pariah during the 2012 festival season. The European Queer Film and Arts Festival Alliance (EQFAFA, queerfilmfestivals.org/alliance), a network of European festival programmers, appealed to Focus Features arguing for the interest and readily accessible international audience, which would assure festival revenue as well as word-ofmouth for DVD sales (on export DVDs). On behalf of EQFAFA, on July 10, 2012, programmer Aurore Maillet of Pink Screens Festival in Belgium wrote a letter to the distributor and to filmmaker Dee Rees. The response from Focus Features was negative:

As you might know Focus Features International does not participate in international film festivals in countries where we do not have local distribution for our films. From an organizational perspective we 
are not able to handle the volume of international film festival requests we receive for all of our films and we also rely on our international partners to decide what works best for a particular film in their territory. However, film festivals are very important to us and to the films we release and so even though we do not have international distribution for PARIAH we decided to put it into the BFI London Film Festival, the International Queer Film Festival in Hamburg and the Out in Africa, Gay \& Lesbian Film Festival, but we are not able to participate in any additional international festivals..$^{21}$

After a last attempt to change their minds Maillet relayed to the EQFAFA that in a phone conversation the Focus Features representative had said that EQFAFA's proposal of centralizing copies and circulation for Pariah had been discussed internally, but was decided against.

The examples of Tomboy and Pariah show the underlying market logics that combine and exclude the realms of IFF and QFF circuit, queer cinema, and arthouse exhibition. Coming back to the example of recent A-list festival programs these trends become more amplified. Of the vast amount of films with queer content that premiered there, some made it to the arthouse circuit while others primarily travelled on the QFF circuit (Concussion and Interior. Leather Bar). The films with the biggest attention (The Kids Are All Right, Brokeback Mountain, La Vie d'Adèle) banked on various strategies. Among the typically employed arthouse strategies are auteurism and the corresponding claim to universalism, post-identitarian universal experience (Adèle), and/or a pledge for tolerance (Brokeback), ${ }^{22}$ as well as using mediatized scandals around taboo-breaking art film for continued buzz.

The distinction of art film is built on the idea of the genius and signature of the author-director, the auteur, who has creative oversight and control over all decisions that feed into the collaborative art form that film is. Both Julianne Pidduck (2011) and David Andrews (2013) point to the connection of the concepts of auteurism and universalism. Within the system of film festivals, the concept of the national as organizing principle had been replaced after the disruption of the Cannes film festival in 1968 and was replaced by a taste-based curator-director logic of selection and programming (De Valck, 2007). Andrews points out that by 'stressing the 'auteur' and other signs of universalism, festivals could better facilitate the international flow of cultural and economic capital on which they depended." (Andrews, 2013: 182). In addition, the presumed universalism is largely equated with the male author and follows the ongoing gender inequality in film production; only very few women have reached auteur status. ${ }^{23}$ Kechiche's non-committed identity position as a straight male director (working discursively as an unmarked auteur ${ }^{24}$ ) works in favor of the common arthouse strategy of declaring a queer film ${ }^{25}$ like La Vie d'Adèle simply a universal love story, by which the queer character of the film is downplayed. Such an argument would not work for out-lesbian filmmakers such as Lisa Cholodenko and her comedy The Kids Are All Right, or debut filmmaker Dee Rees, who publicly framed her script-writing of Pariah as connected to her personal coming-out process.

The logic of La Vie d'Adèle faring as an art film rather than lesbian (identity-driven) queer cinema, then, somewhat paradoxically works well with the strategy that in addition to the Palm d'Or accolades, the film marketing happily rode on various waves of scandal to increase and sustain journalistic buzz and public interest. Even before the film premiered at Cannes, there had been rumors and press fights between cast, crew, and director in which the director was accused of maltreating the two main actresses and generally overworking the crew without compensation (cf. MacCabe, 2013). The work relationship scandal was soon overshadowed by the scandalizing buzz around the seven-minute graphic, lesbian sex scene which started discussions about the representation of sexuality and pornography (cf. Rich, 2013b). This kind of discussion is not new. Art cinema as a genre has a long history of being known for breaking taboos, especially in terms of gender and sexuality. While Hollywood was building its world dominance on classic narrative feature film, which wholesomely followed the Production Code, European art film in turn was 
breaking into the American and other markets by breaking the taboos of sexuality and gender relations that were laid down in the same Production Code. Indeed, the import of European art film helped break down the Production Code and enticed the New Hollywood stories (Andrews, 2013: 177). Nevertheless, as the case of Adèle attests, this mechanism of scandal and the thrill of graphic depiction of queer sex still works very well for creating journalistic buzz today. Indeed, the moment of scandal is a quintessential component of festival reportage, at Cannes and elsewhere (cf. Jungen, 2014). Furthermore, within the French context, the film was framed by the heated discussions, street demonstrations, and violent clashes surrounding the introduction of the samesex marriage law in France coinciding with the festival in May 2013. This context added another layer of meaning in the reception of the film and its award. Beyond general arthouse discussions, the film reception got its own spin in discussions about the credibility and authenticity of the sex scene from within the LGBT/Q community, which have been further fueled by allegations by Julie Maroh, the author of the graphic novel that served as source material, that the sex scenes were unrealistic and pornographic (Child, 2013). These various levels of scandalizing buzz were welldeployed and worked in favor of reaching the attention of the wider arthouse audience. Without these sustained discussions, which have been perpetually rehashed during various release levels (staggered national releases as well as theatrical and DVD release), the film most likely would not have reached such wide distribution and total grossing revenue. ${ }^{26}$

\section{Crossovers and queer relay}

In an account of political queer cinema and mainstream-oriented arthouse distribution one might be tempted to draw up two opposing camps. On the one hand, there would be a community-based queer cinema, produced by determined low-budget independent filmmakers under highly precarious conditions and circulated through and maybe even sustained by the QFF circuit. On the other hand, there would be auteur art cinema, which utilizes queer plotlines as a cheap thrill, divorced from social or community politics, by downplaying queer experience for mainstream publicity, that create big buzz and ride on waves of scandal.

In her chapter "Queer Relay," Lisa Henderson discusses the anxiety that "crossover dreaming," i.e., the crossing from one camp to the other, might bring up. She explains:

In the queer case, crossover dreaming signifies a spatial and cultural polarity between a queer here that is pure and sequestered and thus makes outsiders want in and some denizens want out, and a nonqueer there, mixed, polluted, driven by capital and cultural normativity, both morally compromised and the target of recognition and success - a dream, after all, not conscription. (Henderson, 2013: 101, emphasis in original)

Henderson proposes to think through "formulations that resist that ideological split" where "queerness [is] defiled by markets and commerce" (Henderson, 2013: 101). Using a field-study of the production context for Liza Johnson's queer short film Desert Motel (2005), a project aiming at crossover potential and possible gain in cultural capital for the product and its producers, Henderson teases out the mechanisms - located on the production side - that are at work in the grey areas between idea(l)s of mainstream industry orientation and queer (community) orientation. Several of the markers Henderson gives in the continuum for the "Space of Relay in Queer Cultural Production" (Henderson, 2013: 121) can be applied also to the circulation and distribution context at hand. She suggests that queer-oriented film production (1) imagines a queer world-making in which the world is expressed from a queer perspective for queer recognition rather than aiming to educate the mainstream, (2) is interested in specification and representation as aesthetic and cultural goals rather than "universalism," (3) operates in a stigmaphilic rather than stigmaphobic way, and (4) seeks economic enablement rather than economic clout and wealth (Henderson, 2003: 121). 
In a productive move Henderson reconfigures the movements between mainstream industrial contexts and queer cultural community production as "relay," meaning "an ongoing, uneven process of cultural passing off, catching, and passing on, if not always among members of the same team" which has the potential to form "new subjectivities and alliances between filmmakers, critics, viewers, and cultural citizens" (Henderson, 2013: 103, 127). With this perspective of "queer relay" in mind, I hope the examples in this essay have shown that the relationship between the queer film ecosystem and the larger art film circuit is highly ambivalent. The art film strategies deployed reveal that we are still some way away from actual acceptance and universality in a happy post-gay, postidentitarian world that a quick glance at pop culture might suggest. But the demarcation lines are not clear-cut and current rhetorical strategies are complex. The positions shown on the sides of distinction and cultural capital do not only lean towards exploitation of queer subcultural productions by neoliberal forces but offer a relay position that accounts for queer agency in the wider cultural arena.

\section{Filmography}

Brokeback Mountain (Ang Lee, USA 2005)

Brüno (Larry Charles, USA 2009)

Concussion (Stacie Passon, USA 2013)

Desert Hearts (Donna Deitch, USA 1986)

Desert Motel (Liza Johnson, USA 2005)

Dupã Dealuri /Beyond the Hills (Cristian Mungiu, ROM 2012)

Far From Heaven (Todd Haynes, 2002)

Fremde Haut/Unveiled (Angelina Maccarone, D 2005)

Go Fish (Rose Troche, USA 1994)

Interior. Leather Bar (Travis Mathews, James Franco, USA 2013)

I'm Not There (Todd Haynes, USA 2007)

Keep the Lights On (Ira Sachs, USA 2012)

La vie d'Adèle-Chapitre 1\& 2/Blue Is the Warmest Color (Abdellatif Kechiche, FR 2013)

Laurence Anyways (Xavier Dolan, CAN 2012)

Les adieux à la reine/Farewell, My Queen (Benoît Jacquot, FR 2012)

Lianna (John Sayles, USA 1983)

Mala Noche (Gus van Sant, USA 1985)

Milk (Gus Van Sant, USA 2008)

My Beautiful Laundrette (Stephen Frears, UK 1985)

Nymph()maniac 1+2 (Lars von Trier, DK/D/B/UK/FR 2014)

Pariah (Dee Rees, USA 2007, $27 \mathrm{~min}$ )

Pariah (Dee Rees, USA 2011, 86 min)

Parting Glances (Bill Sherwood, USA 1986)

Personal Best (Robert Towne, USA 1982)

Philadelphia (Jonathan Demme, USA 1993)

Praia do Futuro (Karim Aïnouz, BR/D 2014)

L'Inconnu du lac/Stranger by the Lake (Alain Guiraudie, FR 2012)

Tan de repente/Suddenly (Diego Lerman, ARG/NL 2002)

Tarnation (Jonathan Caouette, USA 2003/2004)

The Birdcage (Mike Nichols, USA 1996)

The Kids Are All Right (Lisa Cholodenko, USA 2010)

Tomboy (Céline Sciamma, FR 2011)

Vic + Flo ont vu un ours/Vic and Flo Saw a Bear (Denis Côté, CAN 2013)

Victim (Basil Dearden, UK 1961)

Wimię... (Małgorzata Szumowska, PL 2013)

Weekend (Andrew Haigh, UK 2012) 


\section{Notes}

1. See the discussion of voting behavior across Europe in Renwick (2014).

2. Following a similar suggestion by Vendula (Esteban) Wiesnerová (2012) I use the common abbreviations of LGBT for lesbian gay bisexual trans* and Q for queer connected with a slash (LGBT/Q) in order to acknowledge the connection as well as the distinction and differentiation of the underlying concepts of gay assimilation vs. radical queer politics behind each term.

3. Box Office Mojo lists The Birdcage (1996) as number 1 of top-grossing films on the list for the Gay/ Lesbian genre marker with a total of over US\$ 124 million, and Brüno coming in at place 8 grossing US\$ 60 million, see http://boxofficemojo.com/genres/chart/?id=gay.htm (accessed June 8, 2014).

4. Paola Gandolfi describes this "accented cinema" as "a cinema which tells the story of the deterritorialization and transitivity of several real and symbolic roads, as well as that of several socio-cultural spaces" (2010: 37).

5. Numbers have been derived from surveying the respective queer awards websites and press coverage around the announcements of festival lineups in trade journals such as IndieWire. For the Berlinale Teddy award see news.teddyaward.tv/; for the Queer Lion at Venice see cinemarte.it/; for the Queer Palm at Cannes see queerpalm.fr; for a queer presence at Sundance see queerlounge.org.

6. The film festival portal and social network site filmfestivals.com boasts a comprehensive directory of 6,000 festivals, and the film submission service provider withoutabox.com advertises serving 5,000 film festivals on six continents (accessed June 11, 2014).

7. "A-list festival" is a colloquial term for the power broker festivals on the circuit. Originally "A-list" meant to denote the festivals, which have been accredited as "Competitive Feature Film Festivals" by the International Federation of Film Producers Association (FIAPF) and, thus, enjoy the guaranteed privilege (and obligation) of hosting an international main competition program, which only shows world (or international) premieres. Currently 14 festivals are listed in the "Competitive" section. The "A-list" section is further accompanied by a number of other accredited festivals grouped as "Competitive Specialized Feature Film Festivals," "Non-Competitive Feature Film Festivals," the so-called best-of festivals, and "Documentary and Short Film Festivals." Practitioners, however, also refer to other festivals which are important on the circuit for premieres or deals, such as the Toronto International Film Festival as A-list festival, despite official designations.

8. Various issues of the Film Festival Yearbook series have been devoted to these kinds of festivals - consider especially Iordanova and Cheung, 2010, Iordanova and Torchin, 2012.

9. For a detailed account of the historical development of the global LGBT/Q film festival circuit see Loist (2013). For a current list of queer film festivals, see queerfilmfestivals.org.

10. Clear, empirical data from systematic research are unavailable (at this moment). Yet, the findings presented are building on long-term observations of the circuit as well as preliminary results from an ongoing empirical study on the circulation of films eligible for the Teddy Award at the Berlinale (conducted together with Ann Vogel, Humboldt Universität Berlin).

11. Marijke de Valck (2007) and Christian Jungen (2014) have both shown that the relationship between Hollywood and the (European) film festival network is more complex and cannot simply be described by pure dichotomy and antagonism. Nevertheless, an underlying distinctly different market logic is visible and significantly influences mechanisms of value-addition and circulation.

12. One of the famous stories tells how the first independently produced low-budget lesbian feature Go Fish (1994) was bought by Samuel Goldwyn Mayer (cf. Pierson 1997). The story of Pariah (2011) shows a similar narrative, albeit with Focus Features as the buyer, one of the most successful specialty divisions that have been established since the 1990s.

13. TFC also has a specialized eye on queer film. Members of the collective have for instance been instrumentally involved in the launching of Jonathan Caouette's cult film Tarnation, which was transformed from a three-hour avant-garde autobiographical documentary which screened at the MIX NYC: Queer Experimental Film Festival in November 2003 into a two-hour cut supported by executive director and indie auteur Gus van Sant, which was then screened at Sundance and Cannes (in the Director's Fortnight sidebar) in 2004. This transformation and unconventional stepping up in the festival hierarchy propelled 
the film into a long run at IFFs and QFFs globally. This success would not have been possible with a mere launch at New York's queer film festival.

14. Such specialized distributors include, in Germany, Edition Salzgeber (founded 1984), ProFun (1993) and GMFilms (1995); in the US, Wolfe Video (founded 1985), Strand Releasing (1989), and TLA Releasing (2001); and in the UK, Tartan Films (1982-2008), and Peccadillo Pictures (2000).

15. The oft-cited anecdote of the "gay ghetto" argument is Chantal Akerman's refusal to have her films screen at LGBT film festivals (cf. Pidduck, 2011: 25)

16. For a detailed discussion of Focus Feature's position, see Tzioumakis 2012. IndieWire reports that Focus Features bought the film immediately at Sundance and even offered Dee Rees a blind script deal, which enabled her to write a new script that she might potentially direct herself (Smith, 2011).

17. Trans* with an asterisk is a way to denote the widest possible meaning of who is included under the trans banner. It comes from a search engines functionality, in which the wildcard * placed after a word will show everything related to it. While this is somewhat specialized knowledge, only noted in writing or code, it has been taken up fairly widely in scholarly writing and by activists. Otherwise, when spoken, "trans" is still heard. Both seek to include all noncisgender gender identities, such as transgender, transsexual, transvestite, genderqueer, genderfluid, non-binary, genderless, non-gendered, third gendered, trans man, trans woman. See Loist and de Valck, 2013.

18. For a detailed discussion of the developments of Frameline, see Loist (2008); for a contextualization of the industry efforts (such as production support and distribution) started by queer film festivals, see Loist and Zielinski (2012).

19. The Kickstarter campaign raised US\$ 11,011 (http://kickstarter.com/projects/619452369/pariahthe-movie). The Frameline Completion Fund awards grants of up to US\$ 5,000; see frameline.org/ filmmaker-support/frameline-completion-fund.

20. See http://butchvoices.com/frameline-35-convo-with-dee-rees-nekisa-cooper-of-pariah and http://ticketing.frameline.org/festival/events/reserve. $a s p x ? i d=3863 \& F I D=48$.

21. Email to Aurore Maillet on July 13, 2012, relayed to the EQFAFA (network@queerfilmfestivals.org).

22. For an instructive discussion of the ethical construction of Brokeback Mountain to appeal to a wide audience, see Bolton (2013).

23. For an elaborate discussion of the connection of gender and sexual identities in the construction of the auteur, see Pidduck (2011: 21-26). Regarding the ongoing gender imbalance in film production see the infographic "Gender Inequality in Film" by the New York Film Academy, available online at: http://nyfa. edu/film-school-blog/gender-inequality-in-film.

24. Although he is otherwise marked as an ethnic director (Rich, 2013b).

25. While the film has largely been discussed as a lesbian film due to the central couple consisting of two women, some critics have pushed the argument that it is a bisexual story (e.g., Plazas, 2014) since Adèle continues to sleep with men and does not follow the strict categorization of a fixed lesbian identity. This argument is in accord with Maria San Filippo's assessment of the potential of bisexuality in art cinema legacy to overcome "compulsory monosexuality and unthink heterosexism" (2010: 89).

26. Collating information available at Box Office Mojo and IMDb, the film was released in 25 countries (Argentina, Australia, Austria, Belgium, Brazil, Colombia, Croatia, Czech Republic, Denmark, Finland, France, Germany, Greece, Hong Kong, Iceland, Italy, Netherlands, New Zealand, Poland, Portugal, Singapore, Spain, Turkey, UK, and Uruguay) and grossed a total of approximately US\$ 15 million in theatrical release (including US domestic, French home market, and foreign revenue).

\section{References}

Aaron M (2012) Passing through: queer lesbian film and Fremde Haut, Journal of Lesbian Studies, 16(3): 323-339.

Andrews D (2013) Theorizing Art Cinemas: Foreign, Cult, Avant-Garde, and Beyond. Austin: University of Texas Press.

Bolton M (2013) The ethics of alterity: adapting queerness in Brokeback Mountain. In P Demory and C Pullen (eds) Queer Love in Film and Television: Critical Essays. Basingstoke: Palgrave Macmillan, pp. 257-268. 
Child B (2013) Blue Is the Warmest Colour sex scenes are porn, says author of graphic novel, The Guardian, May 30, http://theguardian.com/film/2013/may/30/blue-warmest-colour-porn-julie-maroh

de Valck M (2007) Film Festivals: From European Geopolitics to Global Cinephilia. Amsterdam: Amsterdam University Press.

de Valck M (2014) Supporting art cinema at a time of commercialization: principles and practices, the case of the International Film Festival Rotterdam, Poetics, 42: 40-59.

de Valck M and Soeteman M (2010) "And the Winner is ...": what happens behind the scenes of film festival competitions, International Journal of Cultural Studies, 13(3): 290-307.

Elsaesser T (2005) Film festival networks: the new topographies of cinema in Europe. In European Cinema: Face to Face with Hollywood. Amsterdam: Amsterdam University Press, pp. 82-107.

Farahmand A (2010) Disentangling the international festival circuit: genre and Iranian cinema. In R Galt and K Schoonover (eds) Global Art Cinema: New Theories and Histories. New York: OUP, pp. 263-283.

Focus Features (2011) Transforming passion into Pariah: a discussion with writer/director Dee Rees and producer Nekisa Cooper, http://focusfeatures.com/article/transforming_passion_into_pariah?film=pariah

Galt R (2013) Default cinema: queering economic crisis in Argentina and beyond, Screen, 54(1): 62-81.

Galt R and Schoonover K (2010) Introduction: the impurity of art cinema. In R Galt and K Schoonover (eds) Global Art Cinema: New Theories and Histories. New York: OUP, pp. 1-27.

Gandolfi P (2010) Ciné-parcours dans l'Europe contemporaine: routes nécessaires, routes symboliques, Cinémas: Revue d'études cinématographiques, 21(1): 37-57.

Halberstam J J (2012) Gaga Feminism: Sex, Gender, and the End of Normal. Boston: Beacon Press.

Henderson L (2013) Queer Relay, in Love and Money: Queers, Class, and Cultural Production. New York: NYU Press, pp. 101-128.

Iordanova D (2009) The film festival circuit. In D Iordanova and R Rhyne (eds) Film Festival Yearbook 1: The Festival Circuit. St Andrews: St Andrews Film Studies, pp. 23-39.

Iordanova D and Cheung R (2010) Film Festival Yearbook 2: Film Festivals and Imagined Communities. St Andrews: St Andrews Film Studies.

Iordanova D and Torchin L (2012) Film Festival Yearbook 4: Film Festivals and Activism. St Andrews: St Andrews Film Studies.

Jungen C (2014) Hollywood in Cannes: The History of a Love-hate Relationship. Amsterdam: Amsterdam University Press.

Lobato R (2007) Subcinema: theorising marginal film distribution, Limina: A Journal of Historical and Cultural Studies, 13: 113-120.

Loist S (2008) Frameline XXX: thirty years of revolutionary film: Der Kampf um queere Repräsentationen in der Geschichte des San Francisco International LGBT Film Festival. In U. Wischermann and T Thomas (eds) Medien-Diversität-Ungleichheit: Zur medialen Konstruktion sozialer Differenz. Wiesbaden: Verlag für Sozialwissenschaften, pp. 163-181.

Loist S (2010) Queer Film and the Film Festival Circuit. Curator's Note, in media res, mediacommons.futu reofthebook.org/imr/2010/09/14/queer-film-and-film-festival-circuit

Loist S (2012) A Complicated Queerness: LGBT film festivals and queer programming strategies, in J Ruoff (ed.) Coming Soon to a Festival Near You: Programming Film Festivals. St Andrews: St Andrews Film Books, pp. 157-172.

Loist S (2013) The queer film festival phenomenon in a global historical perspective (the 1970s-2000s), in A Fléchet, P Gœtschel, P Hidiroglou, S Jacotot, C Moine, and J Verlaine (eds) Une histoire des festivals: $X X^{\mathrm{e}}-X X I^{\mathrm{e}}$ siècle. Paris: Publications de la Sorbonne, pp. 109-121.

Loist S and de Valck M (2013) Trans* film festivals: an interview with Eliza Steinbock, Necsus - European Journal of Media Studies, http://necsus-ejms.org/trans-film-festivals-an-interview-with-eliza-steinbock

Loist S and Zielinski G (2012) On the development of queer film festivals and their media activism, in D Iordanova and L Torchin (eds) Film Festival Yearbook 4: Film Festivals and Activism. St Andrews: St Andrews Film Studies, pp. 49-62.

MacCabe C (2013) Cannes 2013, Critical Quarterly 55(3): 103-106.

Mezias S, Strandgaard Pedersen J, Kim J, Svejenova S, and Mazza C (2011) Transforming film product identities: the status effects of European premier film festivals, 1996-2005, in B Moeran and J Strandgaard 
Pedersen (eds) Negotiating Values in the Creative Industries: Fairs, Festivals and Competitive Events. Cambridge: CUP, pp. 169-196.

Moore C (2013) Distribution is queen: LGBTQ media on demand, Cinema Journal 53(1): 137-144.

Olson J (2002) Film festivals, in GLBTQ: An Encyclopedia of Gay, Lesbian, Bisexual, Transgender, and Queer Culture, http://www.glbtq.com/arts/film_festivals.html

Peranson M (2008) First you get the power, then you get the money: two models of film festivals, Cineaste 33(3): $37-43$.

Pidduck J (2011) The visible and the sayable: the moment and conditions of hypervisibility,. In F Grandena and C Johnston (eds) Cinematic Queerness: Gay and Lesbian Hypervisibility in Contemporary Francophone Feature Films. Bern: Lang, pp. 9-40.

Pierson J (1997) Spike, Mike, Slackers \& Dykes: A Guided Tour Across a Decade of American Independent Cinema. New York: Miramax Books/Hyperion.

Plazas P (2014) Blue Is the Warmest Color is not a lesbian film, Indiewire, http://blogs.indiewire.com/bent/ vent-blue-is-the-warmest-color-is-not-a-lesbian-film-20140502

Renwick A (2014) Eurovision: a continent divided in its sexual attitudes?, http://blogs.reading.ac.uk/readingpolitics/2014/05/11/eurovision-a-con-tinent-divided-in-its-sexual-attitudes

Rich BR (1992) New queer cinema, Sight \& Sound, 2(5): 30-35.

Rich BR (2000) Queer and present danger, Sight \& Sound, 10(3): 22-25.

Rich BR (2013a) Lethal lesbians: the cinematic inscription of murderous desire. In New Queer Cinema: The Director's Cut. Durham, NC: Duke University Press. pp. 103-122.

Rich BR (2013b) Outrages and obsessions: a report on festival season, Film Quarterly 67(1): 67-72.

San Filippo M (2010) Unthinking heterocentrism: bisexual representability in art cinema. In R Galt and K Schoonover (eds) Global Art Cinema: New Theories and Histories, pp. 75-91. New York: OUP.

Smith N M (2011) Pariah writer/director Dee Rees, Indiewire, http://www.indiewire.com/article/futurespariah-writer-director-dee-rees

Stringer J (2001) Global cities and international film festival economy. In M Shiel and T Fitzmaurice (eds) Cinema and the City: Film and Urban Societies in a Global Context. Oxford: Blackwell, pp. 134-144.

TFC - The Film Collaborative (2013) December 2013, \#1: The Film Collaborative's festival real revenue numbers and comments regarding transparency trends, http://www.thefilmcollaborative.org/_eblasts/ collaborative_eblast_124.html

Tzioumakis Y (2012) Focus Features (2002 to date). In Hollywood's Indies: Classics Divisions, Specialty Labels and American Independent Cinema. Edinburgh: Edinburgh University Press, pp. 177-198.

Walters B (2012) New-wave queer cinema: gay experience in all its complexity, The Guardian, October 4; http://guardian.co.uk/film/2012/oct/04/new-wave-gay-cinema.

Walters B (2013) How gay cinema wooed straight audiences, The Guardian, October 24; https://www.the guardian.com/film/2013/oct/24/gay-cinema-straight-audience-movie

Wiesnerová V(E) (2012) LGBT $Q$ activism and the appropriation of queer theory in Spain. In S Mesquita, MK Wiedlack, and K Lasthofer (eds) Import-Export-Transport: Queer Theory, Queer Critique and Activism in Motion. Wien: Zaglossus, pp. 163-178.

Wong CH (2011) Film Festivals: Culture, People, and Power on the Global Screen. New Brunswick, NJ: Rutgers University Press. 